Original Research Article

\title{
Preclinical screening of a novel compound, 2-chlorothiophene for analgesic activity in swiss albino mice
}

\author{
Surendra Kumar Gondi ${ }^{1 *}$, Muni K. Kummara²
}

${ }^{1}$ Department of Pharmacology, Rangaraya Medical College, Kakinada, Andhra Pradesh, India

${ }^{2}$ Department of Pharmacology, PESIMSR, Kuppam, Chittoor, Andhra Pradesh, India

Received: 02 June 2018

Revised: 15 June 2018

Accepted: 18 June 2018

\section{*Correspondence to:}

Dr. Surendra Kumar Gondi, Email:drgskgovt@yahoo.in

Copyright: (C) the author(s), publisher and licensee Medip Academy. This is an openaccess article distributed under the terms of the Creative Commons Attribution NonCommercial License, which permits unrestricted noncommercial use, distribution, and reproduction in any medium, provided the original work is properly cited

\begin{abstract}
Background: Pain is often the first indication of disease or injury. Analgesics are the drugs used clinically for controlling pain. They relieve pain as a symptom, without affecting its cause. Currently available options are nonsteroidal antiinflammatory drugs (NSAIDs) and opioid analgesics for the management of pain. Long term use of existing analgesics causes significant disturbances in the body system. A search for new, safe and cost effective analgesic compound is in progress. Hence a study on 2-chlorothiophene, a novel compound has been carried out in different experimental animal models.

Methods: The central analgesic activity of 2-chlorothiophene was evaluated by eddy's hot plate method and compared to standard central analgesic, morphine. Both central and peripheral analgesic activities of 2-chlorothiophene were evaluated by formalin induced paw licking in mice and compared to a standard drug, aspirin.

Results: There were $40 \mathrm{mg} / \mathrm{kg}$ dose of 2-chlorothiophene has shown maximum Pain Inhibition Percentage (PIP) of $46.15 \%$ at 60 min compared to $128 \%$ by morphine in eddy's hot plate method. Under Formalin test, $20 \mathrm{mg} / \mathrm{kg}$ dose of 2chlorothiophene has shown maximum PIP of $22.91 \%$ in early phase and $52.63 \%$ in late phase compared to $12.5 \%$ and $47.37 \%$ by aspirin. The results were statistically significant with $\mathrm{p}<0.05$.

Conclusions: 2 -chlorothiophene found to have minimal central analgesic activity and significant peripheral analgesic activity as evident in eddy's hot plate and formalin tests.
\end{abstract}

Keywords: Analgesic, Eddy's hot plate, Formalin test, Thiophene, 2chlorothiophene

\section{INTRODUCTION}

PAIN is defined as an unpleasant sensory and emotional experience associated with actual or potential tissue damage, or described in terms of such damage ${ }^{1,2}$ It may be physiological or pathological.

It is the most frequent reason for seeking medical attention. ${ }^{3}$ It is a major symptom in many medical conditions and can significantly interferes with a person's quality of life and general functioning. ${ }^{4}$ Accessibility of the adequate pain treatment is a human right. ${ }^{5}$
This discomfort of pain can be removed by a group of compounds called analgesics. Long term use of existing analgesics causes adverse effects. Opioids cause adverse effects such as sedation, mental clouding, blurring of vision, respiratory depression, constipation and urinary retention. NSAIDs cause the adverse effects involving several systems of the body such as gastrointestinal tract, kidneys, blood, skin, nervous and cardio vascular systems.

\section{Test compound}

There were 2-chlorothiophene was obtained from PES College of Pharmacy, Bangalore, India. Over the past few 
years, research groups have conducted a comprehensive programme towards the synthesis of thiophene and their fused derivatives which have reported to possess wide range of activity.

It has been reported that the parent compound, thiophene and its derivatives possess analgesic, ${ }^{6}$ anti-inflammatory activities. ${ }^{6,7,8}$ The $\mathrm{LD}_{50}$ values were estimated to be at more than $2 \mathrm{~g} / \mathrm{kg}$ which is far greater than the maximum testing dose in the current study. During this current study, 2chlorothiophene was tested for analgesic activity at 10,20 and $40 \mathrm{mg} / \mathrm{kg}$ doses as the previous studies have proved that the parent compound has predominant analgesic activity at 15 to $30 \mathrm{mg} / \mathrm{kg}$.

\section{METHODS}

Both central and peripheral analgesic activities of 2chlorothiophene were evaluated using experimental animal models such as eddy's hot plate method and formalin induced paw licking in mice. The study was conducted in the Animal house affiliated to the People's Education Society Institute of Medical Sciences and Research, Andhra Pradesh after obtaining approval from the Institutional Animal Ethics Committee. All the animals were handled with gentle care as per the CPCSEA guidelines.

\section{Experimental animals}

The study was carried out in healthy male Swiss albino mice (Mus musculus) weighing between 20 to $25 \mathrm{~g}$ as they are the most widely used strain for assay of analgesics. ${ }^{10}$ Female mice were excluded to avoid the effect of oestrous cycle. They were kept in propylene cages in 12:12 hours light: dark cycle, under standard laboratory conditions and had water ad libitum. Food was withdrawn 12 hours before and during the experiment.

\section{Eddy's hot plate method 11,12}

The paws of mice are very sensitive to heat at temperatures which are not damaging the skin. The time for nociceptive response such as jumping or licking of the paw will be prolonged after the administration of centrally active analgesics. This test has been done to determine the central analgesic activity of 2-chlorothiophene.

\section{Animals}

A total of 30 male Swiss albino mice were taken for this study. Mice which have responded with in 5 seconds were included in the study. ${ }^{13}$

\section{Drugs and reagents}

There were $10 \%$ Tween-80 or Polysorbate-80 (Merck Specialties private limited, Mumbai), was used as a drug suspending agent, as 2-chlorothiophene is water insoluble. Morphine was used as a standard drug and injected intraperitoneally using tuberculin syringe. The test compound, 2-chlorothiophene was administered orally using gavage.

Mice were randomly made into 5 groups each containing 6 in number. Group I was considered as control and received $0.5 \mathrm{ml}$ of Tween-80 per oral. Group II was considered as standard and received morphine-5 $\mathrm{mg} / \mathrm{kg} / \mathrm{ip} .{ }^{14,15}$ Groups III, IV and V were considered as test groups and received 2-chlorothiophene per orally at $10 \mathrm{mg} / \mathrm{kg}, 20 \mathrm{mg} / \mathrm{kg}, 40 \mathrm{mg} / \mathrm{kg}$ respectively. Mice grouped in eddy's hot plate method was shown in Table 1.

\section{Table 1: Group classification of mice in Eddy's hot plate method.}

\begin{tabular}{|lll|}
\hline Group & Drug & Dose \\
\hline I & Control (10\% Tween-80) & $0.5 \mathrm{ml} \mathrm{PO}$ \\
\hline II & morphine & $5 \mathrm{mg} / \mathrm{kg} / \mathrm{ip}$ \\
\hline III & 2-chlorothiophene & $10 \mathrm{mg} / \mathrm{kg} / \mathrm{PO}$ \\
\hline IV & 2-chlorothiophene & $20 \mathrm{mg} / \mathrm{kg} / \mathrm{PO}$ \\
\hline V & 2-chlorothiophene & $40 \mathrm{mg} / \mathrm{kg} / \mathrm{PO}$ \\
\hline
\end{tabular}

Mice were placed on the Eddy's hotplate, a commercially available equipment which consists of an electrically heated copper or glass plate surface, the temperature of which can be maintained between $55-56^{\circ} \mathrm{C}$ to evoke thermal stimulus. Time for response such as jumping or licking of the paw was recorded using a stop watch. The cut-off time, 15 seconds was considered to avoid paw damage. ${ }^{12,16}$

\section{Statistical analysis}

It was done by paired student-t test for comparison between mean value at $0 \mathrm{~min}$ and 20,60 or $90 \mathrm{~min}$ values in each group of mice whereas Analysis of Variance (ANOVA) was applied for the entire model in each group followed by Dunnett's Multiple Comparison Test. The study was found to have statistically significant with a $\mathrm{p}$ value $<0.05$.

\section{Formalin induced paw licking in mice}

\section{Animals}

A total of 30 male Swiss albino mice were taken for this study.

\section{Drugs and reagents}

There were $10 \%$ Tween- 80 or Polysorbate- 80 was used as a drug suspending agent. Aspirin was used as a standard and 2-chlorothiophene as test compound. All drugs were administered orally using gavage.

Mice were randomly made into 5 groups each containing 6 in number. Group I was considered as control and received $0.5 \mathrm{ml}$ of Tween-80 per oral. Group II was 
considered as standard and received aspirin $100 \mathrm{mg} / \mathrm{kg}$ per oral. ${ }^{17,18}$ Groups III, IV and V were considered as test groups and received 2-chlorothiophene per orally at $10 \mathrm{mg} / \mathrm{kg}, 20 \mathrm{mg} / \mathrm{kg}, 40 \mathrm{mg} / \mathrm{kg}$ respectively. Grouping of mice in formalin test was shown in Table 2.

Table 2: Group classification of mice in formalin test.

\begin{tabular}{|lll|}
\hline Group & Drug & Dose \\
\hline I & control (10\% Tween-80) & $0.5 \mathrm{ml} \mathrm{PO}$ \\
\hline II & aspirin & $100 \mathrm{mg} / \mathrm{kg} / \mathrm{PO}$ \\
\hline III & 2-chlorothiophene & $10 \mathrm{mg} / \mathrm{kg} / \mathrm{PO}$ \\
\hline IV & 2-chlorothiophene & $20 \mathrm{mg} / \mathrm{kg} / \mathrm{PO}$ \\
\hline V & 2-chlorothiophene & $40 \mathrm{mg} / \mathrm{kg} / \mathrm{PO}$ \\
\hline
\end{tabular}

The procedure was done as per the standard method suggested by Murray et al and Hunskaar and Hole. ${ }^{11}$ After 1 hour of respective drug administration, $0.02 \mathrm{ml}$ of $5 \%$ formalin was injected into the sub plantar region of hind paw of mice. ${ }^{19}$ (Figure 1).

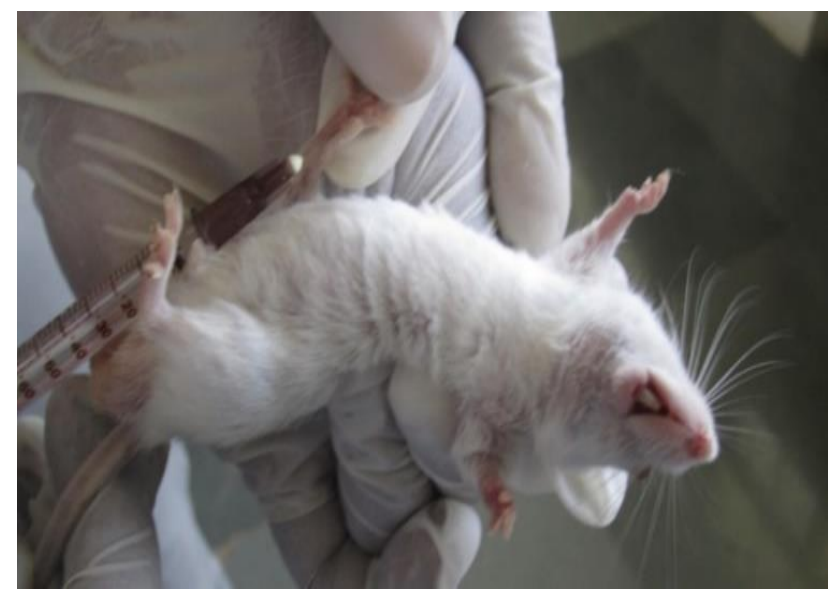

Figure 1: Sub plantar injection of formalin into hind paw of mice.

Pain response was indicated by the paw licking or biting of the paw. Analgesic response was indicated if both paws were resting on the floor with no obvious favouring of the injected paw.

\section{Statistical analysis}

It was done by unpaired student-t test for comparison between control and each drug group whereas ANOVA was applied for the entire model followed by Dunnett's Multiple Comparison Test. The study was found to be statistically significant with significant $\mathrm{p}$ value $<0.05$.

\section{RESULTS}

\section{Eddy's hot plate method}

Latency time was recorded before and after 20, 60 and 90min following administration of the drug.
Table 3: Mean latency time and PIP produced by the control in eddy's hot plate method in mice.

\begin{tabular}{|llll|}
\hline $\begin{array}{l}\text { Recording } \\
\text { time }\end{array}$ & $\begin{array}{l}\text { Mean latency } \\
\text { time }+ \text { SD }\end{array}$ & $\begin{array}{l}\text { PIP } \\
(\%)\end{array}$ & $\begin{array}{l}\text { Paired t test } \\
\text { ( } \mathbf{p} \text { value })\end{array}$ \\
\hline '0' $\min$ & $3.67 \pm 0.03$ & - & - \\
\hline '20' $\min$ & $3.37 \pm 0.03$ & $(-8.17)$ & $<0.0001$ \\
\hline '60' $\min$ & $4.03 \pm 0.04$ & 9.81 & $<0.0001$ \\
\hline '90' $\min$ & $3.57 \pm 0.03$ & $(-2.72)$ & $<0.0001$ \\
\hline
\end{tabular}

ANOVA $\mathrm{p}<0.0001$

Table 4: Mean latency time and PIP produced by morphine-5mg/kg in eddy's hot plate method in mice.

\begin{tabular}{|llll|}
\hline $\begin{array}{l}\text { Recording } \\
\text { time }\end{array}$ & $\begin{array}{l}\text { Mean latency } \\
\text { time } \pm \text { SD }\end{array}$ & $\begin{array}{l}\text { PIP } \\
(\%)\end{array}$ & $\begin{array}{l}\text { Paired t } \\
\text { test } \\
\text { ( } \mathbf{p} \text { value) }\end{array}$ \\
\hline '0' min & $3.78 \pm 0.08$ & - & - \\
\hline '20' min & $6.93 \pm 0.82$ & 83.33 & $<0.001$ \\
\hline '60' min & $8.62 \pm 0.46$ & 128.04 & $<0.0001$ \\
\hline '90' min & $7.48 \pm 0.47$ & 97.88 & $<0.0001$ \\
\hline ANOVA p <0.0001 & & \\
\hline
\end{tabular}

Table 5: Mean latency time and PIP produced by 2chlorothiophene-10 mg/kg in eddy's hot plate method in mice.

\begin{tabular}{|llll|}
\hline $\begin{array}{l}\text { Recording } \\
\text { time }\end{array}$ & $\begin{array}{l}\text { Mean latency } \\
\text { time }+ \text { SD }\end{array}$ & $\begin{array}{l}\text { PIP } \\
(\%)\end{array}$ & $\begin{array}{l}\text { Paired t test } \\
\text { ( } \mathbf{p} \text { value) }\end{array}$ \\
\hline '0' min & $3.52 \pm 0.08$ & - & - \\
\hline '20' $\mathrm{min}$ & $3.83 \pm 0.34$ & 8.81 & $<0.0001$ \\
\hline '60' $\mathrm{min}$ & $4.50 \pm 0.40$ & 27.84 & $<0.0001$ \\
\hline '90' $\mathrm{min}$ & $3.82 \pm 0.04$ & 8.52 & $<0.0001$ \\
\hline
\end{tabular}

ANOVA $\mathrm{p}<0.0001$

Table 6: Mean latency time and PIP produced by 2chlorothiophene-20 mg/kg in eddy's hot plate method in mice.

\begin{tabular}{|llll|}
\hline $\begin{array}{l}\text { Recording } \\
\text { time }\end{array}$ & $\begin{array}{l}\text { Mean latency } \\
\text { time } \pm \text { SD }\end{array}$ & $\begin{array}{l}\text { PIP } \\
(\%)\end{array}$ & $\begin{array}{l}\text { Paired t test } \\
\text { (p value) }\end{array}$ \\
\hline '0' $\min$ & $3.32 \pm 0.18$ & - & - \\
\hline '20' $\min$ & $3.62 \pm 0.15$ & 9.04 & $<0.001$ \\
\hline '60' $\mathrm{min}$ & $4.37 \pm 0.24$ & 31.63 & $<0.001$ \\
\hline '90' $\mathrm{min}$ & $4.07 \pm 0.14$ & 22.59 & $<0.001$ \\
\hline ANOVA p $<0.0001$ & & \\
\hline
\end{tabular}

Table 7: Mean latency time and PIP produced by 2chlorothiophene-40mg/kg in eddy's hot plate method in mice.

\begin{tabular}{|llll|}
\hline $\begin{array}{l}\text { Recording } \\
\text { time }\end{array}$ & $\begin{array}{l}\text { Mean latency } \\
\text { time }+ \text { SD }\end{array}$ & $\begin{array}{l}\text { PIP } \\
(\%)\end{array}$ & $\begin{array}{l}\text { Paired t test } \\
\text { (p value) }\end{array}$ \\
\hline '0' $\min$ & $3.25 \pm 0.24$ & - & - \\
\hline '20' $\mathrm{min}$ & $4.27 \pm 0.58$ & 31.38 & $<0.0001$ \\
\hline '60' $\mathrm{min}$ & $4.75 \pm 0.47$ & 46.15 & $<0.0001$ \\
\hline '90' $\mathrm{min}$ & $4.38 \pm 0.53$ & 34.77 & $<0.0001$ \\
\hline ANOVA p $<0.0001$ & &
\end{tabular}


Prolongation of latency time proves the analgesic activity of the test compound. Prolongation of latency time for 50 to 100 percent was considered positive. ${ }^{11}$

Pain inhibition percentage (PIP) was calculated by comparing the values before and after drug administration. Mean latency time and PIP were determined for control, morphine and test groups separately and shown in Tables 3 to 7 and Figure 2.

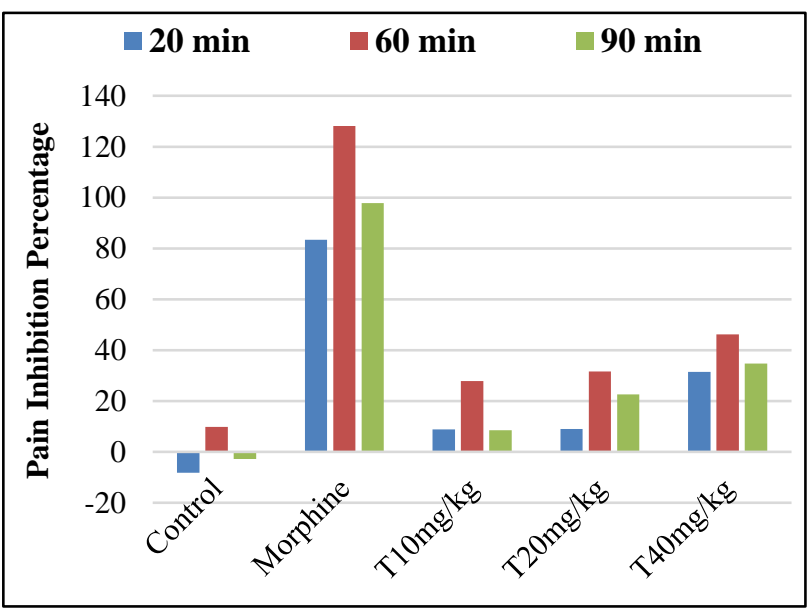

Figure 2: PIP produced by control, morphine and test drug $(\mathrm{T})-10,20$ and 40mg/kg groups at 20, 60 and 90 min in eddy's hotplate method in mice.

\section{Formalin test}

Central analgesic activity of test compound was determined by the early phase whereas the peripheral analgesic action was determined by the late phase of formalin test. Number of paw lickings were recorded in early phase of 0-5 min and in late phase of 20-30 min. ${ }^{20}$ Pain inhibition percentage was calculated by comparing the drug treated values to that of control group.

Pain inhibition percentage was calculated using the formula:

$\mathrm{PIP}=[$ No. of Licks (control-treated group) / No. of Licks in control] X 100

Mean number of paw licks and PIP produced in early and late phases of formalin test shown in Tables 8, 9 and Figure 3.

\section{DISCUSSION}

\section{Eddy's hot plate method}

The PIP produced by the control group of mice at 20,60 and 90 min indicates that no much significant change in latency time. Morphine group of mice has shown maximum PIP at 60 min and can be considered as standard for comparison. ${ }^{21} 40 \mathrm{mg} / \mathrm{kg}$ dose of 2-chlorothiophene has shown maximum action (46.15\%) at 60 min which is far less than that of morphine group (128.04\%).

\section{Formalin induced paw licking test}

\section{Early phase}

The maximum PIP produced by $20 \mathrm{mg} / \mathrm{kg}$ dose of 2 chlorothiophene $(22.91 \%)$ is better than that of $100 \mathrm{mg} / \mathrm{kg}$ dose of aspirin (12.5\%).

\section{Late phase}

The maximum PIP produced by $20 \mathrm{mg} / \mathrm{kg}$ dose of 2 chlorothiophene $(52.63 \%)$ is better than that of $100 \mathrm{mg} / \mathrm{kg}$ dose of aspirin $(47.37 \%)$ as similar to parent thiophene compound. ${ }^{9}$

The study infers that 2-chlorothiophene compound has maximum central analgesic activity at $40 \mathrm{mg} / \mathrm{kg}$ at $60 \mathrm{~min}$ which is lesser than that of $5 \mathrm{mg} / \mathrm{kg}$ dose of morphine and maximum peripheral analgesic activity at $20 \mathrm{mg} / \mathrm{kg}$ which is better than that of $100 \mathrm{mg} / \mathrm{kg}$ dose of aspirin. This study is a simple screening test for the presence or absence of analgesic activity for 2-chlorothiophene compound. The purpose of the study is served by demonstrating the analgesic activity in the doses employed.

It can be considered to have good peripheral analgesic action with maximum PIP of $52.63 \%$ as evident in late phase of formalin test. If the test drug provides substantial positive results under future clinical trials, it's contribution to the community may become very significant as the access to pain management is still very much a human right. $^{22}$

Table 8: Mean No. of paw licks and PIP produced in the early phase of formalin test.

\begin{tabular}{|llll|}
\hline Group & $\begin{array}{l}\text { Mean No. of PIP } \\
\text { licks } \pm \text { SD }\end{array}$ & $\begin{array}{l}\text { Unpaired t } \\
\text { test (p) }\end{array}$ \\
\hline $\begin{array}{l}\text { control } \\
(10 \% \text { tween-80) }\end{array}$ & $32.00 \pm 1.90$ & - & - \\
\hline $\begin{array}{l}\text { aspirin } \\
(100 \mathrm{mg} / \mathrm{kg} / \mathrm{PO})\end{array}$ & $28.00 \pm 1.67$ & 12.50 & $<0.01$ \\
\hline $\begin{array}{l}\text { 2-chlorothiophene } \\
(10 \mathrm{mg} / \mathrm{kg} / \mathrm{PO})\end{array}$ & $28.50 \pm 1.38$ & 10.94 & $<0.01$ \\
\hline $\begin{array}{l}\text { 2-chlorothiophene } \\
(20 \mathrm{mg} / \mathrm{kg} / \mathrm{PO})\end{array}$ & $24.67 \pm 3.33$ & 22.91 & $<0.001$ \\
\hline $\begin{array}{l}\text { 2-chlorothiophene } \\
(40 \mathrm{mg} / \mathrm{kg} / \mathrm{PO})\end{array}$ & $25.50 \pm 2.59$ & 20.31 & $<0.001$ \\
\hline ANOVA p <0.0001 & & & \\
\hline
\end{tabular}

The drug can't be claimed for central analgesic activity as the maximum PIP is $<50 \%$ as evident in eddy's hot plate method and early phase of formalin test. ${ }^{11}$ 
Table 9: Mean No. of paw licks and PIP produced in the late phase of formalin test.

\begin{tabular}{|llll|}
\hline Group (n=6) & $\begin{array}{l}\text { Mean No. } \\
\text { of licks }+ \text { SD }\end{array}$ & $\begin{array}{l}\text { PIP } \\
(\%)\end{array}$ & $\begin{array}{l}\text { Unpaired } \\
\text { t test (p) }\end{array}$ \\
\hline $\begin{array}{l}\text { Control } \\
(10 \% \text { tween-80) }\end{array}$ & $38.00 \pm 2.28$ & - & - \\
\hline $\begin{array}{l}\text { Aspirin } \\
(100 \mathrm{mg} / \mathrm{kg} / \mathrm{PO})\end{array}$ & $20.00 \pm 2.00$ & 47.37 & $<0.0001$ \\
\hline $\begin{array}{l}\text { 2-chlorothiophene } \\
(10 \mathrm{mg} / \mathrm{kg} / \mathrm{PO})\end{array}$ & $22.00 \pm 2.53$ & 42.11 & $<0.0001$ \\
\hline $\begin{array}{l}\text { 2-chlorothiophene } \\
(20 \mathrm{mg} / \mathrm{kg} / \mathrm{PO})\end{array}$ & $18.00 \pm 2.97$ & 52.63 & $<0.0001$ \\
\hline $\begin{array}{l}2-\text { chlorothiophene } \\
(40 \mathrm{mg} / \mathrm{kg} / \mathrm{PO})\end{array}$ & $19.83 \pm 1.47$ & 47.82 & $<0.0001$ \\
\hline
\end{tabular}

ANOVA $\mathrm{p}<0.0001$

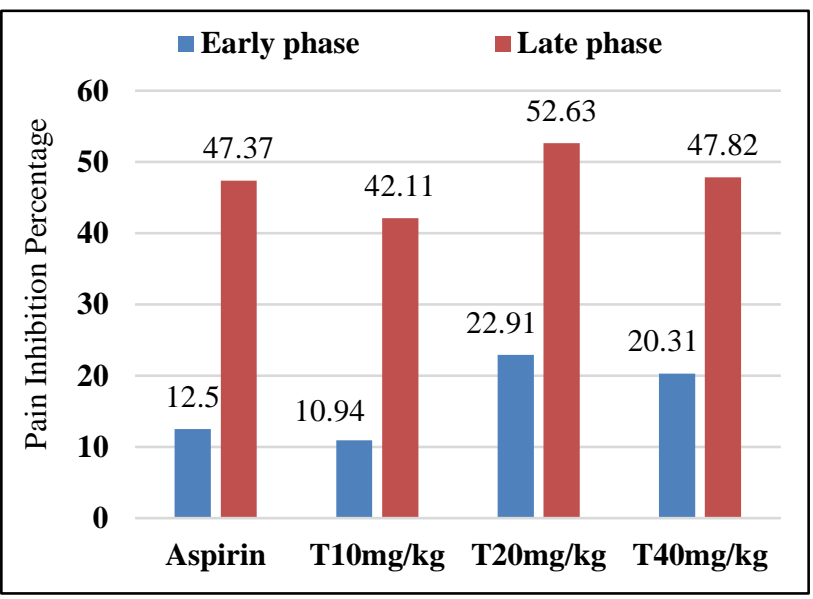

Figure 3: PIP shown by aspirin $(100 \mathrm{mg} / \mathrm{kg})$ and Test $\operatorname{drug}(\mathrm{T})$ at 10,20 and $40 \mathrm{mg} / \mathrm{kg}$ in formalin test.

Under eddy's hot plate method, all drugs have shown peak activity at $60 \mathrm{~min}$ and declined activity at $90 \mathrm{~min}$. If the observations might have been continued, then the complete time course of action for all the drugs could have been recorded. Further studies may be conducted in more number of animal models to evaluate and confirm the findings. These results can't be interpolated for human. Further investigation can throw light on the minimum effective dose and ceiling doses of the drug.

\section{CONCLUSION}

From this study, it can be safely concluded that the test drug, 2-chlorothiophene has good peripheral analgesic action at $20 \mathrm{mg} / \mathrm{kg}$ dose as evident in late phase of formalin test. It has shown maximum central analgesic activity (but $<50 \%$ ) at $40 \mathrm{mg} / \mathrm{kg}$ dose as evident in eddy's hotplate method.

\section{ACKNOWLEDGEMENTS}

Authors would like to thank the Professors and other staff who have provided a lot of support during the conduction of study.
Funding: No funding sources

Conflict of interest: None declared

Ethical approval: The study was approved by the Institutional Animal Ethics Committee

\section{REFERENCES}

1. Part III: Pain Terms, A Current List with Definitions and Notes on Usage. Classification of Chronic Pain, Second Edition, IASP Task Force on Taxonomy, edited by H. Merskey and N. Bogduk, IASP Press, Seattle; 1994:209-217. Available at: http://www.iasppain.org/Education/Content.aspx?ItemNumber=1698 \#Pain. Accessed 21 June 2018.

2. Pain and analgesics. In: Peter N Bennett, Morris J Brown, Pankaj Sharma. Clinical Pharmacology. 11th Ed. Edinburgh: Churchill Livingstone Elsevier;2012:277-93.

3. Torres Rde C, Marques KS, Leal Kde N, Rocha-Filho PA. Main reasons for medical consultations in family healthcare units in the city of Recife, Brazil: a crosssectional study. Sao Paulo Med J.2015;133(4):367-70.

4. Breivik H, Borchgrevink PC, Allen SM, Rosseland LA, Romundstad L, Hals EB, Kvarstein G, Stubhaug A. Assessment of pain. British J anaesthesia. 2008 Jul 1;101(1):17-24.

5. Lohman d, Schleifer r, Amon JJ. Access to pain treatment as a human right. BMC Medicine. 2010;8:8.

6. Srinivasa RV, Saravanan J, Mohan S. Synthesis of 2Substituted-amino-3-(No-tolylcarboxamido)-4, 5dimethyl thiophenes as analgesic and antiinflammatory agents. Ind J Hetero Chem. 1998;8:5962.

7. Ahmed MM, Khan MA, Rainsford KD. Synthesis of thiophene and NO-curcuminoids for antiinflammatory and anti-cancer activities. Molecules. 2013 Jan 25;18(2):1483-501.

8. Revannasiddaiah N, Kumar CA, Kumar GS, Revannaswamy a. Screening of Novel 4chlorothiophene Compound for Anti-inflammatory Activity in Rats. Pharmacologia. 2014;5(8):316-20.

9. W Wardakhan WA, Abdel-Salam OM, Elmegeed GA. Screening for antidepressant, sedative and analgesic activities of novel fused thiophene derivatives. Acta Pharmaceutica. 2008;58(1):1-4.

10. Common Laboratory Animals. In: Ghosh MN. Fundamentals of Experimental Pharmacology. 6th Ed. Kolkata: Ghosh SK and Others;2015:1-13.

11. Central Analgesic Activity In: Vogel HG, Vogel WH, editors. Drug discovery and evaluation: pharmacological assays. Springer Science \& Business Media. 3rd Ed. Newyork: Springer-Verlag Berlin Heidelberg; 2008:984-1030.

12. Eddy NB, Leimbach D. Synthetic analgesics. II. Dithienylbutenyl-and dithienylbutylamines. J Pharmacol Exp Ther. 1953 Mar 1;107(3):385-93.

13. Tambe DA, Chaudhari TB, Chaudhari S. Analgesic activity of Caralluma adscendens roxb.(Aerial parts). Int J Pharm Res Dev. 2010;7:10-4. 
14. Nobre ME, Correia AO, Borges Mde B, Sampaio TM, Chakraborty SA, Goncalves Dde O, et al. Eicosapentaenoic acid and docosahexaenoic acid exert anti-inflammatory and antinociceptive effects in rodents at low doses. Nutr Res. 2013;33(5):422-33.

15. Charkhpour M, Nayebi AR, Doustar Y, Hassanzadeh K. 8-OH-DPAT prevents morphine-induced apoptosis in rat dorsal raphe nucleus: a possible mechanism for attenuating morphine tolerance. Anesthesia \& Analgesia. 2010 Nov 1;111(5):1316-21.

16. Nikajoo LT. Analgesic activity of aqueous and alcohol root extracts of Pergularia daemia (forsk.) chiov. Int J Pharm Pharm Sci. 2009 Nov;1(Suppl 1):33-7.

17. Bhutia YD, Vijayaraghavan R, Pathak U. Analgesic and anti-inflammatory activity of amifostine, DRDE07 , and their analogs, in mice. Indian $\mathrm{J}$ pharmacology. $2010 \mathrm{Feb}$;2(1):17.

18. Shanmugasundaram $\mathrm{P}$, Venkataraman S. Antinociceptive activity of Hygrophila auriculata (Schum) Heine. African Journal of Traditional, Complementary and Alternative medicines (AJTCAM). 2006 Jan 7;2(1):62-9.

19. Okuda K, Sakurada C, Takahashi M, Yamada T, Sakurada T. Characterization of nociceptive responses and spinal releases of nitric oxide metabolites and glutamate evoked by different concentrations of formalin in rats. Pain. May 2001;92(1-2):107-15

20. Hunskaar S, Hole $K$. The formalin test in mice: dissociation between inflammatory and noninflammatory pain. Pain. 1987;30(1):103-14.

21. Gholami M, Saboory E, Mehraban S, Niakani A, Banihabib N, Azad MR, Fereidoni J. Time dependent antinociceptive effects of morphine and tramadol in the hot plate test: using different methods of drug administration in female rats. Iranian J pharmaceutical research: IJPR. 2015;14(1):303.

22. President's Message. Access to Pain Management Still Very Much a Human Right. Pain Medicine. 2016;17:1785-89.

Cite this article as: Gondi SK, Kummara MK. Preclinical screening of a novel compound, 2chlorothiophene for analgesic activity in swiss albino mice. Int J Basic Clin Pharmacol 2018;7:1421-6. 